\title{
Bioenergetics of the Great Basin Pocket Mouse, Perognathus parvus
}

\author{
R. Kent SCHREIBER ${ }^{1}$
}

Schreiber R. K., 1978: Bioenergetics of the Great Basin pocket mouse, Perognathus parvus. Acta theriol., 23, 32: 469-487. [With 2 Figs. \& 4 Tables].

Ingestion rates and annual energy expenditure for the Great Basin pocket mouse, Perognathus parvus, were studied in south-central Washington (Hanford Reservation) during 1970-71 as part of the US/IBP Desert Biome program. Food intake models were derived in relation to time, microenvironmental temperatures, metabolic rate, and coefficient of digestibility. Estimated annual ingestion rates were 2550 and $2462 \mathrm{kcal} / \mathrm{yr}$ for individual males and females, respectively. Summer torpor reduces these costs about $3 \%$. Winter energy expenditure was $40-43 \%$ lower than summer because of more extensive periods of torpor. Estimated daily maintenance energy requirements ranged from a low of 2.36 and $2.63 \mathrm{kcal}$ in the winter to a high of 6.96 and $6.55 \mathrm{kcal}$ in the spring for individual adult males and females, respectively. These estimates indicate $P$. parvus consumes between $4-$ $10 \%$ of its body weight in food per day during the year. Assuming a diet consisting entirely of cheatgrass seeds (Bromus tectorum), individuals require 873-999 seeds per day in the spring and summer, decreasing to about 775 seeds per day in the fall. In the winter, facultative torpor reduces this to less than 400 seeds per day, necessitating the caching of approximately $50-65 \mathrm{~g}$ of seeds. The average annual seed crop would support a maximum density of about 80 animals/ha, indicating this granivore may be periodically food stressed. The overall impact of $P$. parvus on plant succession at the Hanford site is probably minor.

[Dept. Biol. Sci., Univ. Idaho, Moscow, Idaho 83843, USA].

\section{INTRODUCTION}

Energy flow or total assimilation of energy by a population is a fundamental and unifying concept in animal ecology. With the advent of the International Biological Program (IBP), research efforts to estimate

1 Present address: U.S. Fish and Wildlife Service, National Power Plant Team, 1451 Green Road, Ann Arbor, Michigan 48105. Publication №. 1151, Environmental Sciences Division, ORNL. 
and model energy flow in the various biomes greatly increased (for review, see Petrusewicz (ed.) 1967, Petrusewicz \& Ryszkowski (ed.) 1969 and Petrusewicz \& M a c fadyen (ed.) 1970).

Deserts occupy about one-third of the earth's land surface and represent a unique area to investigate energy flow in small mammal consumers. Desert communities have relatively few component populations and their simplified organization offers an opportunity for comprehension of the bioenergetics of a complete system ( $\mathrm{Ch} \mathrm{ew}$ $\& \mathrm{Chew}, 1965)$. The Great Basin, with its sagebrush and grass vegetation, comprises the largest desert in the United States. As rodents are a notable element in the consumer population of this arid region, the study of their bioenergetics is important to the understanding of the variability and magnitude of energy transfer by small mammals in a "cold desert " ecosystem.

This paper examines the bioenergetic aspects of the Great Basin pocket mouse, Perognathus parvus, a granivorous heteromyid that is a common rodent in the northern Great Basin desert ecosystem. Based on laboratory and field studies, first-order estimates of this species' annual energy expenditure are made using a food-intake model. The effects of its energetics on the ecosystem are discussed.

To succeed under the harsh restrictions of the desert environment, heterotherms must maintain a balance between the food resources available in the habitat and the caloric and mineral demands necessary to sustain the appropriate activity for survival and successful reproduction. Aspects of this problem involve both behavioral and physiological adaptations.

Energy flow at any level within an ecosystem (e.g., species, population, community) complies with the general equation:

$$
E_{f}=E_{m}+E_{p}
$$

where $E_{f}$ is total energy flow, $E_{m}$ is total "cost " of maintenance and $E_{p}$ is total "cost " of production (growth and energy storage) for a given time period. In turn, total maintenance $\left(E_{m}\right)$ is the sum of energy dissipated at rest $\left(E_{r}\right)$ and during sessions of activity $\left(E_{a}\right)$ :

$$
E_{m}=E_{r}+E_{a}
$$

For a homeotherm, $\mathrm{McN}$ a b (1963) described energy expenditure as a function of three variables: time, environmental temperature and rate of metabolism. Energy demand in the individual is a function of the temperature gradient between body temperature $\left(T_{B}\right)$ and ambient temperature $\left(T_{A}\right)$. Heat is lost from the body when $T_{A}<T_{B}$ and gained by the body when $T_{A}>T_{B}$. The rate of metabolism is inversely proportional to the temperature gradient at temperatures below thermo- 
neutrality and directly proportional to temperatures above it. The thermoneutral zone, where metabolism is independent of $T_{A}$, is narrow in most desert rodents (D a w s o n, 1955), sometimes represented by a single point of minimum heat production (P e a r son, 1960; $\mathrm{T}$ u ck e r, 1965).

Small rodents, with a relatively large body surface to body weight ratio, gain heat from the environment faster than larger animals. Dissipation of this heat load against a thermal gradient would require evaporative cooling and subsequent water loss - a luxury desert rodents cannot afford. Nocturnalism, torpor, use of burrows and nests, and huddling can mitigate, in part the effects of this physiological stress and modify the subsequent metabolic response. The exigencies of thermoregulation depend on temporal patterning of activity and spatial orientation. Thus, rarely, if ever, do these small, nocturnal animals encounter ambient temperatures that exceed body temperatures. Energy expenditure therefore is concerned primarily with thermogenesis and activity, with additional temporary energy demands during pregnancy and lactation in females.

Seasonal changes in the insulatory properties of the pelage may influence metabolic rates but in small mammals this effect is minimal ( $\mathrm{H}$ a r t, 1956) and has been ignored in this study.

\section{DESCRIPTION OF STUDY AREA}

The primary study site was in the Hanford Works Department of Energy (DOE) Reservation $19 \mathrm{~km}$ northwest of Richland, Benton County, Washington. The $1554 \mathrm{~km}^{2}$ reservation, located in the Columbia Basin, has an average basal plain elevation of $150 \mathrm{~km}$. Climatological and edaphic conditions for the general area have been summarized by $\mathrm{St}$ t ne et al. (1972). During the major period of data collection (June 1970-May 1971) $111 \mathrm{~mm}$ od rain was recorded, $48 \mathrm{~mm}$ less than the long-term average.

Prior to establishment of the reservation in 1943, the general area was used for livestock grazing. Cheatgrass (Bromus tectorum), a highly adaptive winter annual, was introduced into eastern Washington about 1890 (D a u benmire, 1970). Overgrazing and fire permitted this annual to replace most of the native species and it is the dominant grass at the Hanford study area. Shrubby species present include big sagebrush (Artemisia tridentata), bitterbrush (Purshia tridentata), and two species of rabbitbrush (Chrysothamnus nauseosus and C. viscidiflorus). The understory consists of cheatgrass and Sandberg bluegrass (Poa sandbergii). Da ubenmire (1970) includes the area in the Artemisia tridentataPoa association.

\section{METHODS}

\subsection{Microclimate}

Temperatures were recorded continuously at the surface and at the average burrow depth $\left(T_{b}\right)$ of $0.5 \mathrm{~m}$ by a seven day, two-pen thermograph. Data were 
summarized to coincide with the 12 trapping sessions. Mean diurnal surface tem. perature $(T$ ) was calculated as the average of even-hour temperatures from dawr to dusk. Correspondingly, mean nocturnal surface temperatures $\left(T_{n}\right)$ were calculat. ed as the average of even-hour temperatures from dusk to dawn. Burrow temperature $\left(T_{t}\right)$ was calculated as the mean of the daily maximum and minimum subsurface temperature.

\subsection{Trapping}

Rodent populations were sampled monthly using snap-traps spaced approxim. ately $3 \mathrm{~m}$ apart, with 50 traps per line. Rolled oats paste was used for bait. Sex weight, position of testes and number of embryos or placental scars were recordec for each individual. Age classes were established by weight and pelage color. Al gravid or lactating females were considered adults.

Rodents live-trapped for use in assimilation trials were maintained in laboratory cages on diets including rat chow, rolled oats, sunflower seeds, mixed birc seeds, and occasional "greens $\alpha$.

\subsection{Calorimetry}

I determined energy content of materials by combustion in a Parr oxyger bomb calorimeter using standard procedures. When quantity permitted, three replicate samples were burned and the average used as the caloric equivalent Values were corrected for fuse wire combustion, nitric acid production, and ash

\subsection{Seed Production}

To obtain an estimate of available seed resources, cheatgrass, the dominan annual and preferred food item for $P$. parvus, was sampled in three consecutive years (1970-72). Collections were made in late May prior to seed fall. Entire cheatgrass plants were harvested on 20 plots $\left(0.1 \mathrm{~m}^{2}\right)$ spaced at $3 \mathrm{~m}$ intervals along three parallel transect lines. Seed production was derived from the density. production function of $\mathrm{Hulbert}$ (1955, Fig. 15). Average seed weight was determined from seeds removed from cheek pouches of trapped mice. Seed biomass $\left(\mathrm{g} / \mathrm{dm}^{2}\right)$ was calculated as the product of average seed production and the average seed weight.

\subsection{Digestibility}

The coefficient of digestibility was measured directly in laboratory animals $(\mathrm{N}=19)$ and indirectly for animals living in the field (pooled sample, $\mathrm{N}=30$ ) For direct measurement live-trapped animals were acclimated to captivity for at least 5 days, then fed the test diet for 24 hours prior to trials to insure that the recovered feces represented the test diet. Pre-weighed food (Purina lab chow rolled oats, or sunflower seeds) was available to test individuals for $3-5$ days.

Ingestion was calculated as the difference between initial and final food weights, after correction for changes in water content. Coefficient of digestibility was calculated directly:

$$
\mathrm{D}_{1}=\left(\frac{I-F}{I}\right) \times 100
$$

where $I$ is ash-free weight of ingested food and $F$ is the ash-free dry weight of resulting feces.

For animals in the wild, living on native foods, an indirect measurement, the ash-tracer technique (Conover, 1966; Johnson \& M a xel1, 1966), was 
used. This method assumes that the animal maintains a mineral balance with ash loss equaling ash intake and that the feces recovered from the rectum are residues of the same dietary constituents as those found in the stomach. Coefficient of digestibility was calculated:

$$
D_{2}=\left[1-\frac{\left(1 / y_{c}\right)-1}{\left(1 / y_{o}\right)-1}\right] \times 100
$$

where $y_{c}$ is the proportion of ash in the feces with a correction for additional ash loss in the urine, and $y_{o}$ is the proportion of ash in the stomach material. Ash loss in the urine was assumed to be the same as that measured for individuals maintained in the laboratory on a variety of diets.

\subsection{Estimation of Individual Energy Expenditure}

I calculated ingestion rates by considering the species' activity in field-encountered microclimates (surface and burrows) and the resulting metabolic demands. Adjustments were made for the energy cost of reproduction and for the insulating properties of the nest since both factors influence ingestion rates.

Ingestion rates were calculated using the model:

$$
I=\left[\left(E_{r}+E_{a}\right)+E_{a_{3}}\right] D^{-1}=\left(E_{m}+E_{q_{3}}\right) D^{-1}
$$

where $I$ is ingestion rate (kcal/ $\mathrm{yr}), E_{r}$ and $E_{a}$ are energy costs while resting and during activity, $E_{m}$ is their sum (maintenance), $E_{a_{3}}$ is energy costs for growth from weaning to subadult, and $D$ is coefficient of digestibility. Females incur additional energy demands during pregnancy and lactation as a result from respiration and growth of the embryos. Embryonic respiration has been accounted for by including gravid females in calculations of mean weight. Therefore, ingestion rates for females were calculated as:

$$
I q=\left[\left(E_{m}+p E_{q_{1}}+w E_{g_{2}}+E_{g_{3}}\right\rfloor\left(D^{-1}\right)\right.
$$

where $p$ is mean brood size at parturition (i.e., mean litter size $\times$ average number of litters per year), $w$ is the mean brood size at weaning (i.e., mean brood size ( $p$ ) - mortality during nursing period), and $E_{a_{1}}$ and $E_{a_{2}}$ are energy costs for growth from conception to birth and from birth to weaning, respectively. Intrauterine mortality has been ignored.

Mean litter size was based on counts of visible embryos or placental scars. Females with either embryos or placental scars were recorded as bearing one litter: females with bath embryos and scars or scars of an undetermined number were recorded as having two litters. Any additional production between the subadult and adult stage is taken into account by using the average adult weight when calculating the energy for maintenance $\left(E_{m}\right)$.

\subsection{Energy Costs at Rest and in Torpor}

Resting metabolic rates $(R M R)$ and energy demand in torpor $\left(E_{t}\right)$ were taken from the literature. Metabolic rates of animals occupying a nest $\left(E_{n}\right)$ were estimated by adjusting the rate of metabolism at rest as indicated by $\mathrm{Pears}$ on (1960).

\subsection{Energy Cost of Activity}

Since metabolic rate increases during periods of activity, I monitored aboveground activity of free-roaming mice tagged with a radioactive nuclide. Individuals 
were live-trapped, anesthesized, and a small length (4-10 $\mathrm{mm}$ ) of tantalum-182 (half-life 115 days, $1.2 \mathrm{mev}$ ) wire implanted subcutaneously in the loose skin between the scapula. Eeach wire $(100-200 \mu \mathrm{ci})$ was encapsulated in catheter tubing.

Tagged individuals were released near their point of capture and their location underground determined by use of a portable Geiger-Muller survey meter (Eberline E-120) equipped with an audio speaker and a modified scintillation probe ( $\mathrm{S} \mathrm{h} \mathrm{r}$ e ibe r, 1973). Attempts to monitor above-ground activity of completely free-roaming individuals failed since tagged rodents did not establish "resident" burrows.

To circumvent this problem, two sheet metal enclosures (circumference $15.2 \mathrm{~m}$, area $18.5 \mathrm{~m}^{2}$ ) buried to a depth of about $30 \mathrm{~cm}$ were placed in the field. Plywood nest boxes with plastic tubes opening at the surface were buried in each enclosure. Radionuclide-tagged mice were released in the enclosures and their periods of above-ground activity continously recorded by a battery operated monitoring device consisting of a $\mathrm{NaI}$ gamma scintillation probe, count rate meter and strip chart recorder (S chreiber, 1973). Estimates of daily and seasonal variation in activity were based on these field results, personal communications from other field investigators and published data (French et al. 1966).

The amount of energy expended in activity $\left(E_{a}\right)$ is taken from information cited in $\mathrm{Chew} \& \mathrm{Chew}$ (1970).

\subsection{Energy Cost of Growth}

Energy expended in growth is represented by the general equation:

$$
E_{g}=(W K)\left(G^{-1}\right)
$$

where $E_{g}$ is the energy cost for growth during a specific stage of development and each stage of growth is the product of the weight gain $(W)$ and tissue caloric value $(K)$ divided by growth efficiency $(G)$.

\section{RESULTS AND DISCUSSION}

\subsection{Annual Energy Expenditure and Ingestion Rates}

Depending on ambient temperature and food availability, $P$. parvus is normally active on the surface from March to October. Metabolic rates for this species have been measured by several investigators (Anderson, 1970; Guthrie, 1972; M e e ha n, 1975). Guthrie's equations, based on numerous replications, for energy expended during rest $\left(E_{r}\right)$ and torpor $\left(E_{t}\right)$ are:

$$
\begin{gathered}
E_{r}=8.61-0.24 T_{b} \quad\left(T_{b}>21.3^{\circ} \mathrm{C}\right) \quad \mathrm{N}=67 \\
E_{t}=0.38+0.01 T_{b} \quad \mathrm{~N}=32
\end{gathered}
$$

where $T_{b}$ is burrow temperature. An active animal incurs an additional energy loss of about $2.9 \mathrm{ml} \mathrm{O}_{2} \mathrm{ghr}^{-1}$ ( $\left.\mathrm{Chew} \& \mathrm{Ch} \mathrm{ew}, 1970\right)$. Therefore, energy expended for activity $\left(E_{\mathrm{a}}\right)$ is:

$$
E_{a}=11.51-0.24 T_{A}
$$

The insulation of nests afford rodents resting in burrows additional protection against heat loss. Scheffer (1938) found nests for $P$. parvus at depths ranging $86-193 \mathrm{~cm}$. However, in this study, nesting 
chambers, found in only 5 of 26 burrow excavations, had an average depth of $48 \mathrm{~cm}$ (range $35-61 \mathrm{~cm}$ ). A well-formed nest, located in chamber $10 \times 10 \times 6 \mathrm{~cm}$ at a depth of $58 \mathrm{~cm}$, weighed $3.5 \mathrm{~g}$ and consisted primarily of cheatgrass stems, seed husks and other plant debris. Based on a progressive decrease in the radiation detected, a radionuclide-tagged pocket mouse increased the depth of its resting area as temperatures dropped in the fall. Kenagy (1973) reported similar vertical movement in Perognathus longimembris. To account for this behavior, subsurface temperatures taken at $91 \mathrm{~cm}$ (Stone et al. 1972) were used to calculate metabolic expenditures of torpid and resting animals during the colder months (Fig. 1).

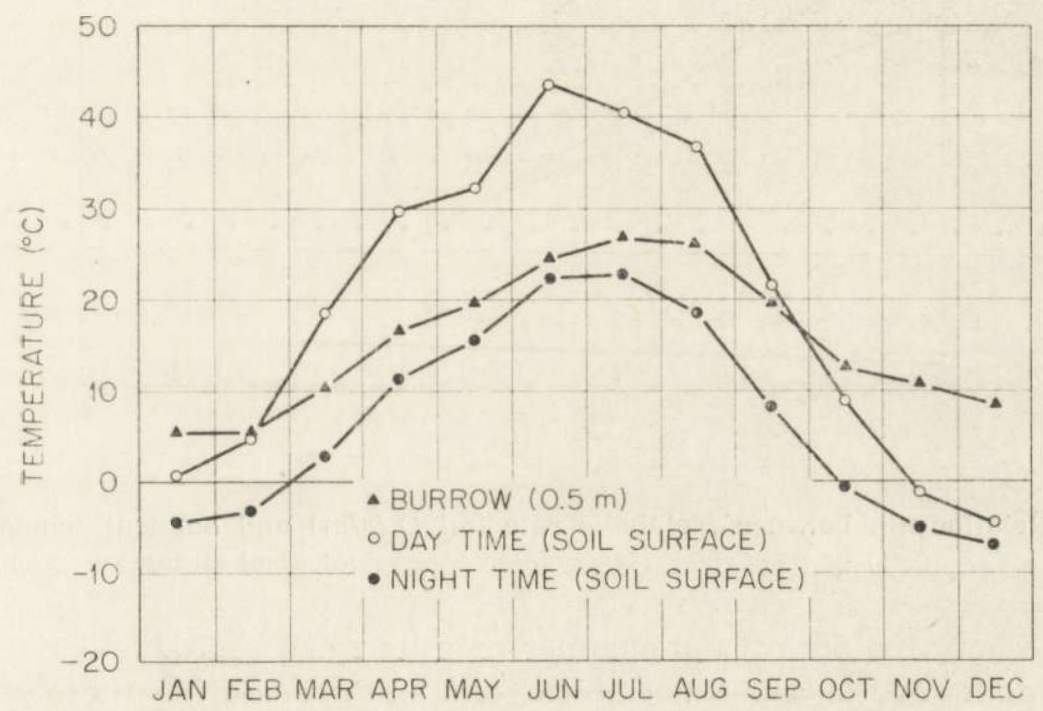

Fig. 1. Microenvironmental temperatures at the Hanford site, June 17, 1970 - June 16, 1971.

Metabolic rate reductions due to the insulating effects of the nest were plotted as $0.81 E_{r}$ at $1^{\circ} \mathrm{C}$ and $0.87 E_{r}$ at $12^{\circ} \mathrm{C}$, based on data for a harvest mouse in a natural nest (P e a r s o n, 1960, Fig. 1), and which are comparable to data for Dipodomys microps and Dipodomys merriami ( $\mathrm{K}$ e $\mathrm{n}$ a g y, 1973). The equation fitting the line for energy expended in the nest $\left(E_{n}\right)$ is:

$$
E_{n}=7.0-0.165 T_{b} \quad\left(T_{b}<21.3^{\circ} \mathrm{C}\right)
$$

Setting $E_{n}$ equal to $E_{r}, T_{A}=21.3^{\circ} \mathrm{C}$. Above this temperature the nest offers no savings in energy (Fig. 2).

To determine requirements for maintenance $\left(E_{M}\right)$, the energy used for 
activity $\left(E_{a}\right)$, torpor $\left(E_{t}\right)$ and rest $\left(E_{r}\right.$ or $\left.E_{\mathrm{n}}\right)$ must be quantified in terms of time. Monitoring results in the spring indicate a radionuclide-tagged mouse was active above ground about 5 hours/night, similar to the results reported for Perognathus formosus in the Mohave desert (French, et al., 1966). This amount of activity would presumably

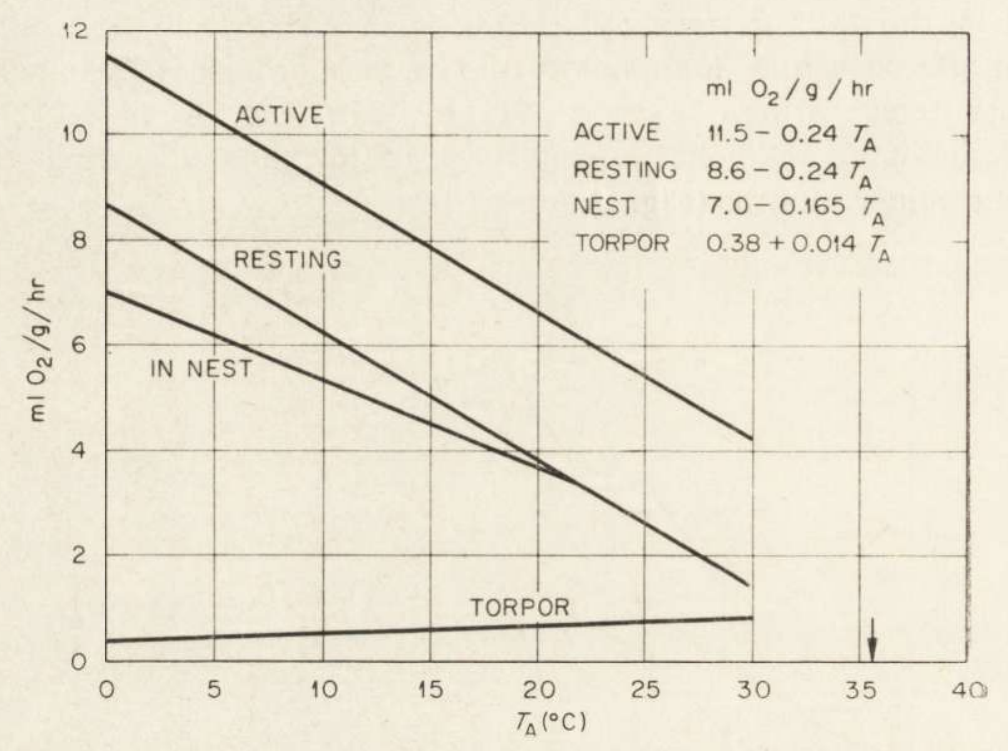

Fig. 2. Relationship between metabolic rate $\left(\mathrm{ml} \mathrm{O}_{2} / \mathrm{g} / \mathrm{hr}\right)$ and ambient temperature $\left(T_{A}\right)$ in $P$. parvus during selected physiological states.

apply to both the spring and summer months when reproductive activity and foraging are at a peak. Ambient temperatures during these seasons exact minimum energy costs for thermoregulation in $P$. parvus.

Based on trapping success ( $\mathrm{C} \mathrm{hreiber}$, 1973), activity is greatly reduced in the fall prior to torpor and during the cooler part of early spring. Males are active later in the fall and earlier in the spring than females. I estimated the activity time during these transition periods (Tables 1 and 2).

Based on field recordings animals were seldom exposed to burrow temperatures below $5^{\circ} \mathrm{C}$ (Fig. 1). Since this species accumulates no appreciable body fat, their overwinter survival depends on food caches and periodic torpor ( $\mathrm{Schreiber} \& \mathrm{Johnson}$, 1975). Although heteromyids are highly individualistic in their proclivity for torpor, the pattern and periodicity is apparently a function of the amount of food stored and environmental conditions of the habitat ( $\mathrm{Brown}$ \& Bartholomew, 1969; Tucker, 1966; Meehan, 1975). During 
the coldest part of the year (mid-November to mid-March) the aboveground activity of this species is severely curtailed or absent. In years with high populations and late litters, subadults may be active into

Table 1.

Estimated daily activity and annual maintenance energy expenditure for a male Perognathus parvus.

\begin{tabular}{|c|c|c|c|c|c|c|c|c|c|}
\hline \multicolumn{2}{|c|}{ Time Interval } & \multirow{2}{*}{$\begin{array}{c}\text { Body Wt. } \\
\text { (g) }\end{array}$} & \multicolumn{3}{|c|}{ Hours Daily } & \multicolumn{4}{|c|}{ Metabolic Costs (kcal)a } \\
\hline Dates & Days & & $\begin{array}{l}\text { At } \\
\text { Rest }\end{array}$ & $\begin{array}{l}\text { In } \\
\text { Torpor }\end{array}$ & Active & $E_{r}$ & $E_{t}$ & $E_{a}$ & $E_{m}$ \\
\hline $17-6 / 28$ & 12 & 1917 & 16 & 3 & 5 & 49.5 & 2.3 & 33.7 & 85.5 \\
\hline $6 / 29-8 / 3$ & 3 & & 16 & 3 & 5 & 110.4 & 6. & 96.5 & 213.3 \\
\hline $8 / 4-9 / 10$ & 3 & 1 & 16 & 3 & 5 & 111.5 & 6.7 & 105.3 & 223.5 \\
\hline $9 / 11-10 / 12$ & 32 & 16.42 & 11 & 11 & 2 & 105.4 & 18.0 & 48.4 & 171.8 \\
\hline $10 / 13-11 / 15$ & 34 & 15. & 12.5 & 11 & 0.5 & 155.1 & & 14.9 & 185.3 \\
\hline $11 / 16-12 / 5$ & 20 & $16.19 \mathrm{~b}$ & 4 & 20 & 0 & 32.6 & 15.5 & 0 & 48.1 \\
\hline $12 / 6-1 / 1$ & 27 & 16.8 & 4 & 20 & 0 & 48.9 & & 0 & 70.3 \\
\hline $1 / 2-2 / 4$ & 34 & $17.52^{\mathrm{b}}$ & 4 & 20 & 0 & 69.8 & 24.6 & 0 & 94.4 \\
\hline $2 / 5-3 / 12$ & 36 & 1 & 3.5 & 20 & 0.5 & 67.1 & 28 & 19.5 & 114.9 \\
\hline $3 / 13-4 / 11$ & 30 & 18.85 & 11 & 11 & 2 & 159.7 & 14.9 & 59.4 & 234.0 \\
\hline $4 / 12-5 / 11$ & 30 & 1969 & 8 & 11 & 5 & 96.5 & 18.6 & 125.7 & 240.8 \\
\hline $5 / 12-6 / 16$ & 36 & 19.02 & 16 & 3 & 5 & 194.6 & 6.4 & 127.4 & 328.4 \\
\hline \multirow[t]{2}{*}{ Annual $\mathrm{T}$} & \multirow{2}{*}{\multicolumn{4}{|c|}{$\begin{array}{l}1 \text { (kcal/yr) with summer torpor } \\
\left(\% E_{m}\right) \\
\text { without summer torpor } \\
\left(\% E_{m}\right)\end{array}$}} & & $\begin{array}{l}1201.1 \\
(59.7)\end{array}$ & $\begin{array}{r}178.4 \\
(8.9)\end{array}$ & $\begin{array}{l}630.8 \\
(31.4)\end{array}$ & 2010.3 \\
\hline & & & & & & $\begin{array}{c}1286.4 \\
(62.1)\end{array}$ & $\begin{array}{r}153.0 \\
(7.4)\end{array}$ & $\begin{array}{l}630.8 \\
(31.4)\end{array}$ & 2070. \\
\hline
\end{tabular}

a Based on microenvironmental temperatures (Fig. 1).

b Estimated body weight used a constant proportion of the known average weight gain over winter.

December and January (O'F a r rell, et al., 1975). However, this deviation in seasonal activity is apparently related to above-average winter annual vegetation production and has therefore been ignored when calculating average energy requirements for the species.

Torpor bouts in $P$. parvus may last from $3-240$ hours (I vers o n, 1967; Hayden \& Lindberg, 1970; Meehan, 1975). During the coldest months they spend about $60-80 \%$ of their time in torpor (C he w et al., 1965; I verson, 1967) sc an estimate of 20 hours torpor daily was used to calculate average winter energy costs.

During the early fall and early spring, torpor permits metabolic savings between the intermittent periods of surface activity and resting in the nest. Tucker (1962) reported diurnal torpor in Perognathus californicus at $15^{\circ} \mathrm{C}$, even with free access to food. At this temperature with moderate food rations, this species averaged 11 hours (range $7-15$ ) in torpor (T u cker, 1966). Perognathus formosus at $17^{\circ} \mathrm{C}$ spent about 10 hours/day in torpor (Browe r \& $\mathrm{C}$ a de, 1971). I used 11 hours of - 
torpor to calculate metabolic costs in $P$. parvus during the spring and fall.

It is unknown if $P$. parvus exibits summer torpor (estivation) under natural conditions. In summer when food is more available and burrow temperatures are high, torpor might seem less advantageous. However, it may serve as an important means of conserving body water and

Table 2

Estimated daily activity and annual maintenance energy expenditure for a female Perognathus parvus at the Hanford site.

\begin{tabular}{|c|c|c|c|c|c|c|c|c|c|}
\hline \multicolumn{2}{|c|}{ Time Interval } & \multirow{2}{*}{$\begin{array}{l}\text { Body Wt. } \\
\text { (g) }\end{array}$} & \multicolumn{3}{|c|}{ Hours Daily } & \multicolumn{4}{|c|}{ Metabolic Costs (kcal)a } \\
\hline Dates & Days & & $\begin{array}{l}\text { At } \\
\text { Rest }\end{array}$ & $\begin{array}{l}\text { In } \\
\text { Torpor }\end{array}$ & Active & $E_{r}$ & $E_{t}$ & $E_{a}$ & $E_{m}$ \\
\hline $6 / 17-6 / 28$ & 12 & 17.47 & 16 & 3 & 5 & 45.1 & 2.2 & 30.7 & 78.0 \\
\hline $6 / 2$ & 36 & & 16 & 3 & 5 & 100.6 & 6.6 & 89.2 & 196.4 \\
\hline $8 / 4-9 / 10$ & 38 & 16. & 16 & 3 & 5 & 114.5 & 6.8 & 108.1 & 229.4 \\
\hline $9 / 11-10 / 12$ & 32 & $17.3^{3}$ & 12 & 11 & 1 & 121.6 & 19.1 & 25.5 & 166.2 \\
\hline $10 / 13-11 / 15$ & 34 & 16.6 & 12.5 & 11 & 0.5 & 166.5 & 16.4 & 16.0 & 198.9 \\
\hline $11 / 16-12 / 5$ & 20 & 15.9 & 4 & 20 & 0 & 29.4 & 23.0 & 0 & 52.4 \\
\hline $12 / 6-1 / 1$ & 27 & 1 & 4 & 20 & 0 & 44.3 & 10.8 & 0 & 64.1 \\
\hline $1 / 2-2 / 4$ & 34 & 14.5 & 4 & 20 & 0 & 58.0 & 21.4 & 0 & 79.4 \\
\hline $2 / 5-3 / 12$ & 36 & $13 . \varepsilon$ & 4 & 20 & 0 & 58.4 & 21.6 & 0 & 80.0 \\
\hline $3 / 13-4 / 11$ & 30 & 13.16 & 12 & 11 & 1 & 121.7 & 10.4 & 20.6 & 152.7 \\
\hline $4 / 12-5 / 11$ & 30 & 15.31 & 8 & 11 & 5 & 75.7 & 14.6 & 98.1 & 188.4 \\
\hline $5 / 12-6 / 16$ & 36 & 16.67 & 16 & 3 & 5 & 170.5 & 5.6 & 111.6 & 287.7 \\
\hline \multicolumn{6}{|c|}{$\begin{array}{l}\text { Annual Total (kcal/yr) with summer torpor } \\
\qquad\left(\% E_{m}\right)\end{array}$} & $\begin{array}{l}1106.3 \\
(62.4)\end{array}$ & $\begin{array}{r}167.5 \\
(9.4)\end{array}$ & $\begin{array}{l}499.8 \\
(28.2)\end{array}$ & 1773.6 \\
\hline \multicolumn{3}{|c|}{ without summer } & \multicolumn{3}{|c|}{$\begin{array}{l}\text { torpor } \\
\left(\% E_{m}\right)\end{array}$} & $\begin{array}{l}1186.8 \\
(64.7)\end{array}$ & $\begin{array}{r}146.3 \\
(8.0)\end{array}$ & $\begin{array}{r}499.8 \\
(28.2)\end{array}$ & 1832.9 \\
\hline
\end{tabular}

a Based on microenvironmental temperatures (Fig. 1).

b Estimated body weight based a constant proportion of the known average weight gain over winter.

energy between periods of reproductive activity and foraging. Circumstantial evidence indicates a tendency for at least periodic bouts of summer torpor in this genus. For example, $\mathrm{M}$ e e han (1975) reported $P$. parvus in the laboratory entered torpor spontaneously in the presence of hoarded food at 18 and $6^{\circ} \mathrm{C}$ during both summer and winter. Iverson (1967) found torpid $P$. parvus in live traps from April to November and reported spontaneous torpor (in the presence of food) occurred in the laboratory at temperatures up to $20^{\circ} \mathrm{C}$. Others (e.g., Bartholomew \& Cade, 1957; Bartholomew \& MacMille $n, 1961$ ) have found heteromyids are easily induced into torpor at temperatures from $5-22^{\circ} \mathrm{C}$ when starved. $\mathrm{C}$ a de (1964), in his discussion of the evolution of torpidity in rodents, states 12 species of Perognathus exhibit varying degrees of torpor at temperatures $5-25^{\circ} \mathrm{C}$. 
Periodic bouts of summer torpor for $P$. parvus have been suggested by O'Farrell et al. (1975). At ambient temperature $24^{\circ} \mathrm{C}$ and with food, Chew et al. (1965) found the little pocket mouse, Perognathus longimembris, was hypometabolic $12.5 \%$ of the time. However, French (1976) studying hibernation in this species concluded it probably does not become torpid during the summer months since it selects the most advantageous (highest) subsurface temperatures available during the year and that torpor would occur only when this temperature is significantly below minimum (lower critical) temperature of thermal neutrality. For purposes of comparison, summer metabolic requirements were calculated both with and without the possible savings of torpor. Based on the data of $\mathrm{Ch}$ e w et al. (1965) I assumed 3 hours of daily torpor, as might occur during summers with low cheatgrass production (food restriction) and/or extreme microclimate conditions (thermal stress, dehydration).

Pocket mice are solitary animals and it is doubtful whether individuals huddle during cold weather. Pairs housed together in the laboratory were pugnacious and one usually died. Often the dead animal showed little or no sign of physical injury, suggesting death may have been caused by stress. In the field $\mathrm{S} c \mathrm{~h}$ e f f e r (1938) never found more than a single mouse using a winter nest. Therefore, it is unlikely huddling is a significant method of reducing thermoregulatory costs in $P$. parvus.

Estimates of the annual costs for maintenance $\left(E_{m}\right)$ in male and female pocket mice are given in Tables 1 and 2 . To calculate the individual's annual ingestion rate, the additional energy expenditure for growth is needed. For the male it includes only growth after weaning (Eq. 6). For the females however this energy cost must also include the expense of bearing and raising young (Eq. 7).

Weight gains $(W)$ were determined for each growth stage. The average weight of $P$. parvus born in the laboratory was $1.27 \mathrm{~g}(\mathrm{~N}=5)$, approximating the greatest weight of an embryo found in utero. Weight of embryonic tissues increases this $27 \%$ ( $\mathrm{Ka} \mathrm{c} \mathrm{z} \mathrm{marski}, 1966$ ). Weaning weight was considered $6.4 \mathrm{~g}$, the weight of the smallest pocket mousecaptured. Subadult weights for males and non-gravid females were 13.0 and $11.5 \mathrm{~g}$, respectively. I used the following caloric values for the tissues $(K)$ : for the embryo, $0.98 \mathrm{kcal} / \mathrm{g}$ fresh weight, based on the average caloric values of five species of newborn rodents (Gór e cki, 1965; Myrcha \& Walkowa, 1968; Soholt, 1973); for the unweaned young, $1.39 \mathrm{kcal} / \mathrm{g}$, assuming an average weaning age of 25 days and the mean caloric value of two species of rodents ( $\mathrm{M} \mathrm{y} \mathrm{ch} \mathrm{h}$ \& Walkowa, 1968; Soholt, 1973), and for weaned young, 1.55 
kcal/g (Schreiber \& Johnson, 1975). Lacking specific data for growth efficiency $(G)$ during gestation and lactation, I used that calculated by $\mathrm{Kaczmarski}$ (1966) for the bank vole (Clethrionomys glareolus) and by Migula (1969) for the common vole (Microtus arvalis). Based on the average of these values, $G=13.8 \%$ for embryos and $15.0 \%$ for unweaned young. The efficiency of growth in weaned young was assumed equal to efficiencies determined for the common vole from weaning up to the age of 50 days ( $\mathrm{r}$ o ż $\mathrm{d} \dot{z}$ et al. 1972), i.e., $G=5.0 \%$.

The cost for growth from weaning to subadult was calculated as:

$$
\begin{aligned}
& E_{g_{3}}=(W K)\left(G^{-1}\right) \\
& \sigma^{\top}=(6.6)(1.55) / 0.05=204.6 \mathrm{kcal} \\
& q=(5.1)(1.55) / 0.05=158.1 \mathrm{kcal}
\end{aligned}
$$

Using a coefficient of digestibility of $89.2 \%$, based on animals living in the wild on natural diets, the annual ingestion rate for an individual male was calculated (Eq. 6):

$$
\begin{aligned}
& I \sigma^{*}=(2010+205) / 0.892=2483 \mathrm{kcal} / \mathrm{yr} \text { (with summer torpor) } \\
& \text { or }=(2070+205) / 0.892=2550 \mathrm{kcal} / \mathrm{yr} \text { (without summer torpor) }
\end{aligned}
$$

Females have an additional energy increment for producing young. Mean litter size for P. parvus at the Hanford site in 1970-1971 was 3.9 $(\mathrm{N}=82)$. This is smaller than values reported for this species in southern British Columbia (4.8, I v e r s o n, 1967), southeastern Washington (5.2, $\mathrm{Sch}$ effer, 1938), Utah (5.4, D uke, 1957) and Nevada (5.6, H a ll, 1946). Females normally raise $1-2$ litters per year. During this study the average number of litters per year was $1.10(\mathrm{~N}=57)$. I have assumed a conservative survival rate of $80 \%$ for nursing young ( $\mathrm{K} \mathrm{a} \mathrm{c} \mathrm{z} \mathrm{m} \mathrm{a} \mathrm{r} \mathrm{s} \mathrm{k} \mathrm{i,}$ 1966). The coefficient of digestibility of females was $91.1 \%$. Annual ingestion rate for an individual female was calculated as:

$$
\begin{gathered}
I q=\left(E_{m}+p E_{g_{1}}+w E_{g_{2}}+E_{g_{3}}\right)\left(D^{-1}\right) \\
=(1774+49+153+158) / 0911=2342 \mathrm{kcal} / \mathrm{yr} \text { (with summer torpor) } \\
=(1883+360) / 0.911=2462 \mathrm{kcal} / \mathrm{yr} \text { (without summer torpor) }
\end{gathered}
$$

Of the total energy expended in growth $\left(E_{g}\right)$, an individual animal used $13.6 \%$ from conception to birth, $42.5 \%$ from birth to weaning and $43.9 \%$ from weaning to subadult.

From the energy required annually for maintenance, $P$. parvus spent approximately $60-65 \%$ during rest, $7-9 \%$ in torpor and $27-31 \%$ in activity (Tables 1 and 2). Summer torpor would permit an annual energy savings of about $3 \%$. Because of extensive torpor, daily energy expenditure in the winter is estimated as only $40-43 \%$ of that required in the summer. 


\subsection{Ecological Implications}

Cheatgrass seeds formed a major portion of the pocket mouse's diet at the Hanford site ( $\mathrm{S} c \mathrm{hr}$ eiber, 1973). The productivity of such winter annuals fluctuates greatly from year to year, apparently in response to the time and amount of precipitation ( $\mathrm{S} n \mathrm{eva}$, 1965; B e a t l e y, 1967, 1969). Cheatgrass seed production during three grow-

Table 3

Annual cheatgrass production at the Hanfond study sites, 1970-1972.

\begin{tabular}{|c|c|c|c|c|c|c|}
\hline Year & Site & $\begin{array}{l}\text { Density } \\
\text { (plants } / 0.1 \mathrm{~m}^{2} \\
\pm \mathrm{SE})\end{array}$ & $\begin{array}{c}\text { Culms } \\
\text { (culms } / 0.1 \mathrm{~m}^{2} \\
\pm \mathrm{SE} \text { ) }\end{array}$ & $\begin{array}{l}\text { Seed densitya } \\
\quad\left(\mathrm{no} / \mathrm{dm}^{2}\right)\end{array}$ & $\begin{array}{l}\text { Biomass } \\
(\mathrm{k} / \mathrm{ha})\end{array}$ & $\begin{array}{l}\text { Caloricc } \\
\text { value } \\
\text { (Mcal/ha) }\end{array}$ \\
\hline 1970 & Arc 6 & $94.2 \pm 13.1$ & $96.9 \pm 13.1$ & 18 & 30.5 & 140 \\
\hline 1971 & B-27 & $38.4 \pm 3.7$ & $39.3 \pm 3.9$ & 24 & 40.7 & 187 \\
\hline 1972 & B-27 & $30.0 \pm 4.7$ & $33.4 \pm 4.6$ & 26 & 44.1 & 203 \\
\hline Mean & & $54.2 \pm 4.7$ & $56.5 \pm 4.8$ & 22.6 & 38.4 & 177 \\
\hline
\end{tabular}

a $\mathrm{H}$ u l bert (Fig. 15, 1955).

b Based on average of 590 seeds/gram.

c Caloric value of cheatgrass seeds is $4.61 \mathrm{kcal} / \mathrm{g}$ (S c h r e i b e r, 1973).

Table 4

Estimated daily maintenance energy requirements and food consumption in adult Perognathus parvus at the Hanford site.

\begin{tabular}{|c|c|c|c|c|c|c|c|c|}
\hline \multirow{2}{*}{$\begin{array}{l}\text { Time } \\
\text { interval }\end{array}$} & \multirow{2}{*}{$\begin{array}{c}\text { Length } \\
\text { (days) }\end{array}$} & \multirow{2}{*}{$\begin{array}{l}\text { Mean } \\
\text { hody } \\
\text { weight } \\
\text { (g) }\end{array}$} & \multicolumn{4}{|c|}{ Energy requirements } & \multicolumn{2}{|c|}{$\begin{array}{l}\text { Daily seed } \\
\text { consumptionb }\end{array}$} \\
\hline & & & kcal/day & $\begin{array}{l}\text { Percent } \\
B M R(\%)^{\text {a }}\end{array}$ & $\mathrm{kcal} / \mathrm{g}$ & $\mathrm{kcal} / \mathrm{g} / \mathrm{hr}$ & gc & No.d \\
\hline \multicolumn{9}{|c|}{ Male } \\
\hline $2 / 5-6 / 16$ & 132 & 18.9 & 6.96 & 195 & 0.368 & 0.015 & 1.69 & 999 \\
\hline $6 / 17-9 / 10$ & 86 & 17.9 & 6.07 & 178 & 0.339 & 0.014 & 1.48 & 873 \\
\hline $9 / 17-11 / 15$ & 66 & 16.0 & 5.41 & 172 & 0.338 & 0.014 & 1.32 & 776 \\
\hline $11 / 16-2 / 4$ & 81 & 16.8 & 2.63 & 83 & 0.156 & 0.006 & 0.64 & 379 \\
\hline \multicolumn{9}{|c|}{ Female } \\
\hline $3 / 13-6 / 16$ & 96 & 15.0 & 6.55 & 218 & 0.437 & 0.018 & 1.55 & 920 \\
\hline $6 / 17-9 / 10$ & 86 & 17.0 & 5.86 & 182 & 0.405 & 0.017 & 1.64 & 969 \\
\hline $9 / 11-11 / 15$ & 66 & 17.0 & 5.53 & 166 & 0.325 & 0.014 & 1.32 & 777 \\
\hline $11 / 16-3 / 12$ & 117 & 14.9 & 2.36 & 80 & 0.158 & 0.006 & 0.56 & 332 \\
\hline
\end{tabular}

a Basal metabolic rate $(B M R)=70 \mathrm{~W}^{0.75}, \mathrm{~W}=$ body weight $(\mathrm{kg})$ (K l e i b e r, 1961).

b Digestibility coefficients; male $=0.892$, female $=0.911$.

c Based on $4.61 \mathrm{kcal} / \mathrm{gram}$ of cheatgrass seeds.

d Based on 590 seeds/gram, 1 seed $=1.69 \mathrm{mg}$.

ing seasons averaged $38 \mathrm{~kg} / \mathrm{ha}$ or $177 \mathrm{Mcal}$ (Table 3). Assuming a diet consisting entirely of cheatgrass seeds, the estimated daily seed consumption by adult $P$. parvus at the Hanford site is given in Table 4 . 
These values indicate pocket mice consume about $4-10 \%$ of their body weight in food per day for maintenance. Summer values are comparable to the daily consumption values Ander s on (1970) gave for $P$. parvus at $20-30^{\circ} \mathrm{C}$. Based on my torpor estimates, seed caches of about $46 \mathrm{~g}$ for males and $60 \mathrm{~g}$ for females would be required to insure overwinter survival. Stored seeds probably amount to $60-70 \mathrm{~g}$ based on the reported volume of excavated caches ( $\mathrm{S} \mathrm{ch}$ effer, 1938; Iverson, 1967).

Using these calculations, an individual pocket mouse would require about 262,000 to 289,000 cheatgrass seeds per year. Given that I have reasonably estimated periods of daily activity in this species (i.e., $839-919 \mathrm{hrs} / \mathrm{yr})$, an individual would need to collect about 300 seeds per hour of surface activity to satisfy the predicated maintenance energy demands.

In the semi-arid lowlands of southern British Columbia I ver s o n (1967) found $P$. parvus had a home range of $656-895 \mathrm{~m}^{2}$. O'F a r r e 1 et al. (1975), studying populations at somewhat higher elevations on the Hanford Reservation, calculated an average home range of $2140 \mathrm{~m}^{2}$ for adults. Assuming these estimates of home range size are valid for my study area and given the average seed deposition rate of $2260 / \mathrm{m}^{2}$ (Table 3 ), then there are approximately $1.5-2.0 \times 10^{6}$ cheatgrass seeds potentially available to an individual within its area of normal activity, or between 5 to 8 times its predicted annual energy requirements.

There is some evidence however that this species is periodically resource stressed. Densities during peak years may exceed 100/ha (O'F a r rell et al., 1975); in fact, results from snap-trapping in my study area suggested populations may exceed 180/ha ( $\mathrm{S}$ ch reiber, 1973). Data from O'F a r r ell et al. (1975) indicates an inverse relationship between population density and home range size. Their data suggest that at densities greater than 100 /ha the home range may actually be less than $500 \mathrm{~m}^{2}$. Even with smaller home range sizes these densities would require considerable overlap and competition for the available seeds. With an average seed crop and a conservative estimate of 50-95\% seed recovery ( $\mathrm{O}$ d u m et al.. 1962: C h e w \& $\mathrm{Ch}$ e w, 1970; Soholt, 1973), the maximum sustainable population would range between 39-83 animals/ha. Although this species consumes other types of seeds, plant parts, and even insects (particularly in the spring), one would expect substantial mortality before the next breeding season whenever populations exceed about 80/ha.

Recently, R e i c h m a n (1977a) presented evidence that in the southern deserts there is considerable competition between heteromyids and ants. If similar circumstances exist in the northern cold deserts, my 
estimates of maximum sustainable populations would require reduction. Birds appear less specific in their use of cheatgrass seeds (Go e bel $\&$ B e r ry, 1976) and are probably less competitive with $P$. parvus. Interestingly, at the Hanford site there are presently no other heteromyids and this lack of interspecific competition common to its southern counterparts may permit comparatively higher densities during years of high cheatgrass production.

R e ichman (1977b) suggested heteromyids reduce the number of seeds required to meet their energy demands by selecting seed species that are energetically appropriate. In the case of $P$. parvus, annual grass seeds $(\sim 4.6 \mathrm{kcal} / \mathrm{g})$ represent the most available seed source (K r i tzman, 1974; S chreiber, 1973), although certain high energy seeds, such as Salsola iberica $(5.7 \mathrm{kcal} / \mathrm{g})$, may be seasonally important in their diet. It has been shown that heteromyids may exert considerable influence on certain plant species by their preferencial seed predation and browsing (e.g., Soholt, 1973; Me e han et al., 1977) which in turn could affect plant succession. At Hanford, the extensive use of cheatgrass seeds implies such potential. Obviously some seeds escape detection and many surface caches may not be relocated. When a large percentage of these seeds are removed however, germinating plants have less competition for soil nutrients and moisture and respond with greater seed production ( $\mathrm{Hulbert}$, 1955). Therefore the total effect of $P$. parvus on cheatgrass abundance is probably small. The major forcing function directing the system probably lies instead in the pattern and amount of annual precipitation (e.g., B e a t l e y, 1969; O'F a r r ell et al., 1975). To exploit a food source that demonstrates oscillating annual differences in yield and comprises only about $7 \%$ of the vegetation production. $P$. parvus must therefore, (1) be highly efficient in collecting seeds and in assimilating their energy, and (2) rely on the use of facultative torpor throughout the year to balance the residual energy demands.

\footnotetext{
Acknowledgements: This paper represents a portion of my dissertation submitted in partial fulfillment of the requirements for a Doctor of Philosophy degree in Zoology from the University of Idaho. Special thanks go to my major professor, Dr. Donald R. Johnson, for his many helpful suggestions and numerous hours spent in the field. I would also like to acknowledge the excellent support of the staff at the Joint Center for Graduate Study, Richland, Washington and the use of field facilities at the Utah State University Ecology Field Station, Snowville, Utah. This research was supported in part through the US/IBP Desert Biome program, under Grant \#GB 15886 from the National Science Foundation; in part by a NORCUS appointment (U.S. Atomic Energy Commission (now Department of Energy), Contract No. AT(45-1-2042) with Battelle, Pacific Northwest Laboratories, Richland; and in part by the Department of Energy under contract with Union Carbide Corporation, Oak Ridge National Laboratory, Environmental Sciences Division, Oak Rige TN.
} 


\section{REFERENCES}

1. Anderson S. H., 1970: Effect of temperature on water loss and $\mathrm{CO}_{2}$ production of Perognathus parvus. J. Mammal., 51: 619-620.

2. Bartholomew G. A., \& Cade T. J., 1957: Temperature regulation, nibernation, and aestivation in the little pocket mouse, Perognathus longimembris. J. Mammal., 38: 60-72.

3. Bartholomew G. A. \& M a Millen R. E., 1961: Oxygen consumption, estivation and hibernation in the Kangaroo mouse, Microdipodops pallidus. Physiol. Zool., 34: 171-178.

4. B eatley J. C., 1967: Survival of winter annuals in the northern Mojave Desert. Ecology, 48: 745-750.

5. B e a tley J. C., 1969: Dependence of desert rodents on winter annuals and precipitation. Ecology, 50: 721-724.

6. Brower J. E. \& $\mathrm{Cade}$ T. J., 1971: Bicircadian torpor in pocket mice. BioScience, 21: 181-182.

7. Brown J. H. \& Bartholomew G. W., 1969: Periodicity and energetics of torpor in the kangaroo mouse, Microdipodops pallidus, Ecology, 50: 705709 .

8. C a d e T. J., 1964: The evolution of torpidity in rodents. Ann. Acad. Sci. Fenn., IV Biol., 71 (6): 79-112.

9. Chew R. M. \& Chew A. E., 1965: The primary productivity of a desert shrub (Larrea tridentata) community. Ecol. Monogr., 35: 355-375.

10. Chew R. M. \& Chew A. E., 1970: Energy relationships of the mammals of a desert shrub (Larrea tridentata) community. Ecol. Monogr., 40: 1-21.

11. Chew R. M., Lindberg R. G. \& Hayden P., 1965: Circadian rhythm of metabolic rate in pocket mice. J. Mammal., 46: 477-494.

12. C on over R. J., 1966: Assimilation of organic matter by zooplankton. Limnol. Oceanogr. 11: $338-345$.

13. Da u benmire R., 1970: Steppe vegetation of Washington. Washington State Agri. Exp. Sta. Tech. Bull. 62, Coll. of Agri., Washington State Univ. 131 p.

14. D a w s on W. R., 1955: The relation of oxygen consumption to temperature in desert rodents. J. Mammal., 36: 543-553.

15. Drożdż A., Górecki A. \& Sawicka-Kapusta K., 1972: Bioenergetics of growth in common voles. Acta theriol., 18: 245-257.

16. Duke K. L., 1957: Reproduction in Perognathus. J. Mammal., 38: 207-210.

17. French A. R., 1976: Selection of high temperatures for hibernation by the pocket mouse, Perognathus longimembris: ecological advantages and energetic consequences. Ecology, 57: 185-191.

18. French N. R., Maza B. G. \& A s chwanden A. P., 1966: Periodicity of desert rodent activity. Science, 154: 1194-1195.

19. G oebel C. J. \& Berry G. 1976: Selectivity of range grass seeds by local birds. J. Range Manage., 29: 393-395.

20. Górecki A., 1965: Energy values of body in small mammals. Acta theriol., 10: $333-352$.

21. Guthrie D. R., 1972: The effect of torpor on pulmo-cutaneous water loss in Perognathus parvus. Ph. D. dissertation, Univ. British Columbia, Vancover. $81 \mathrm{p}$ 
22. H a 11 E. R., 1946: Mammals of Nevada. Univ. California Press: 1-710. Berkeley.

23. H a r t J. S., 1956: Seasonal changes in insulation of the fur. Canadian J. Zool., 34: $53-57$.

24. H a y den P. \& Lindberg R. G., 1970: Hypoxia-induced torpor in pocket mice (Genus: Perognathus). Comp. Biochem. Physiol., 33: 167-179.

25. Hulbert L. C., 1955: Ecological studies of Bromus tectorum and other annual bromegrasses. Ecol. Monogr., 25: 181-213.

26. I vers on S. L., 1967: Adaptations to arid environments in Perognathus parvus (Peale). Ph.D. Dissertation, Univ. British Columbia. 130 p.

27. J ohns on D. R. \& M a xel1 M. H., 1966: Energy dynamies of Colorado pikas. Ecology, 47: 1057-1061.

28. K a c z marski F., 1966: Bioenergetics of pregnancy and lactation in the bank vole. Acta theriol., 11: 409-417.

29. K en a y G. J., 1973: Daily and seasonal patterns of activity and energetics in a heteromyid rodent community. Ecology, 54: 1201-1219.

30. Kleiber M., 1961: The Fire of Life. John Wiley \&Sons, Inc: 1-454. New York.

31. Kritzman E. B., 1974: Ecological relationship of Peromyscus maniculatus and Perognathus parvus in eastern Washington. J. Mammal., 55: 172-188.

32. $\mathrm{M} \mathrm{c} \mathrm{N} \mathrm{a} \mathrm{b} \mathrm{B.} \mathrm{K.,} \mathrm{1963:} \mathrm{A} \mathrm{model} \mathrm{of} \mathrm{the} \mathrm{energy} \mathrm{budget} \mathrm{of} \mathrm{a} \mathrm{wild} \mathrm{mouse.} \mathrm{Ecology,}$ 44: $521-532$.

33. Meehan T., 1975: Profound spontaneous torpor in Perognathus parvus. Amer. Soc. Mammalogists 55th Ann. Mtg. (Abstr.), Univ. Montana, Missolula.

34. Meehan T., Rundel P. W., Ambrose R., Baker G. \& Rappaport A., 1977: The influence of intense selective browsing by pocket mice (Perognathus) on the spatial distribution of Polygala deserticum in Baja California Amer. Midl. Nat., 97: 489-495.

35. Migula P., 1969: Bioenergetics of pregnancy and lactation in European common vole. Acta theriol., 14: 167-179.

36. M y cha A. \& Walkowa W., 1968: Changes of the caloric value of the body during the postnatal growth development of white mice. Acta theriol., 13: $391-400$.

37. Odum E. P., Connel1 C. E. \& Davenport L. B., 1962: Population energy flow of three primary consumer components of old-field ecosystems. Ecology, 43: $88-96$.

38. O'Farrel1 T. P., Olson R. J., Gilbert R. O. \& Hedlund J. D., 1975: A population of Great Basin pocket mice, Perognathus parvus, in the shrubsteppe of southcentral Washington. Ecol. Monog., 45: 1-28.

39. Pears on O. P., 1960: The oxygen consumption and bioenergetics of harvest mice. Physiol. Zool., 33: 152-160.

40. Petrusewicz K. (ed.), 1967: Secondary productivity of terrestrial ecosystems (Principles and Methods). Państw. Wyd. Nauk.: 1: 1-379. Warszawa.

41. Petrusewicz K: \& Macfadyen A. (ed.), 1970: Productivity of terrestrial animals, principles and methods. IBP Handbook No. 13. F. A. Davis, Co: 1-190. Philadephia, Pennsylvania.

42. Petrusewicz K. \& Ryszkowski L. (ed.), 1969: Energy flow through small mammal populations. Państw. Wyd. Nauk.: 1-298. Warszawa. 
43. Reichman O. J., 1977a: Field experiments on seed use by desert rodents and ants. Amer. Soc. Mammalogists 57th Ann. Mtg. (Abstr.), Michigan State Univ., East Lansing.

44. Reichman O. J., 1977b: Optimization of diets through food preferences by heteromyid rodents. Ecology, 58: $454-457$.

45. Scheffer T. H., 1938: Pocket mice in Washington and Oregon in relation to agriculture. U. S. Dept. Agr. Tech. Bull. No. 608: 1-15.

46. Schreiber R. K., 1973: Bioenergetics of rodents in the northern Great Basin desert. Ph.D. dissertation, Univ. Idaho, Moscow. $133 \mathrm{p}$.

47. Schreiber R. K. \& Johnson D. R., 1975: Seasonal changes in body composition and caloric content of Great Basin rodents. Acta theriol., 20: $343-364$.

48. Sneva F. A., 1965: Cheatgrass yields and precipitation fluctuations, p. 2729. Proc. Cheatgrass Symp., July 27-30, 1965. U.S. Dept. of Interior, BLM, Oregon-Washington State Office. $92 \mathrm{p}$.

49. Soholt L. F., 1973: Consumption of primary productivity by a population of kangaroo rats (Dipodomys merriami) in the Mojave Desert. Ecol. Monog., 43: $357-376$.

50. Stone W. A., Jenne D. E. \& Thorp J. M., 1972: Climatology of the Hanford Area. BNWL-1605, June 1971 Battelle Pacific Northwest Lab., Richland, Washington.

51. Tucker V. A., 1962: Diurnal torpidity in the California pocket mouse. Science, $136: 380-381$.

52. Tucker V., A., 1965: Oxygen consumption, thermal conductance, and torpor in the California pocket mouse, Perognathus californicus. J. Cell. Comp. Physiol., 65: 393-404.

53. Tucker V. A., 1966: Diurnal torpor and its relation to food consumption and weight changes in the California pocket mouse Perognathus californicus. Ecology, 47: 245-252.

Accepted, May 10, 1978.

\section{R. Kent SCHREIBER}

\section{BIOENERGETYKA PEROGNATHUS PARVUS}

\section{Streszczenie}

U Perognathus parvus, odławianych w poludniowo-centralnym Waszyngtonie (rezerwat Hanford) zmierzono zużycie pokarmu i roczne wydatki energetyczne. Zużycie pokarmu badano w zależności od czasu, tempa metabolizmu, temperatur mikrośrodowiska i współczynnika strawności (Ryc. 1 i 2). Oszacowane w ten sposób zapotrzebowanie pokarmowe jest równe 2550 i $2462 \mathrm{kcal} / \mathrm{rok}$ odpowiednio dla samicy i samca. W lecie, dzięki okresowym odrętwieniom, koszt energetyczny zmniejsza się o około $3 \%$. Zimą, kiedy okresy odrętwienia są wydłużone, wydatki energetyczne są o $40-43 \%$ niższe niż latem (Tabela 1 i 2 ). Dobowy koszt energetyczny zwierząt zimujących jest najniższy i wynosi $2,36 \mathrm{kcal} / \mathrm{samca}$ i $2,63 \mathrm{kcal} / \mathrm{samicę}$. Najwyższy zaś jest na wiosnę osiągając odpowiednio dla dorosłej samicy i samca wartości 6,96 i 6,55 kcal (Tabela 4), co świadczy, iż $P$. parvus konsumuje dziennie pokarm stanowiący $4-10 \%$ ciężaru swego ciała. Przeliczając te ilości na pokarm 
złożony wyłącznie z nasion Bromus tectorum wykazano, iż jeden osobnik potrzebuje 873-999 nasion/dobę wiosną i latem i około 775 nasion jesienią. W zimie, dzięki fakultatywnemu odrętwieniu ilość ta zmniejsza się do około 400 (Tabela 4).

Zbadano również produkcję nasion Bromus tectorum (Tabela 3) i obliczono, że średni roczny plon nasion tej trawy umożliwia wyżywienie dla maksymalnie 80 osobników/ha. Ponieważ $\mathrm{w}$ latach szczytu liczebności zagęszczenie badanego gatunku jest większe może mieć tu miejsce stress pokarmowy. Przypuszcza się, że rze-czywista presja $P$. parvus na sukcesję traw jest mniejsza niż wynika to $z$ prezentowanych wyliczeń. 